\title{
ResearchArticle
}

\section{Phytochemical analysis of certain aromatic medicinal plants of Sivasagar district, Assam especially alkaloid and saponin}

\author{
N. BARUWATI AND N. BARUAH
}

\section{SUMMARY}

This paper deals with presence of alkaloid and saponin in certain aromatic medicinal plants of sivasagar district which is used by the different tribes of Assam for treatment of different diseases. In this phytochemical analysis, total of 38 plant species were collected and analysed. 20 species were found with the presence of alkaloid and 09 species with the saponins. In 3 species both alkaloid and saponin were found.

Key Words : Aromatic plants, Phytochemical analysis

How to cite this article: Baruwati, N. and Baruah, N. (2016). Phytochemical analysis of certain aromatic medicinal plants of Sivasagar district, Assam especially alkaloid and saponin. Internat. J. Plant Sci., 11 (2): 355-358, DOI: 10.15740/HAS/IJPS/11.2/355-358.

Article chronicle : Received : 01.02.2016; Revised : 31.05.2016; Accepted : 27.06.2016

\section{MEMBERS OF THE RESEARCH FORUM}

Author to be contacted :

N. BARUAH, Department of Botany, Sibsagar Girls' College, SIVASAGAR (ASSAM) INDIA

Email: nibaditabaruwati21@gmail.com

Address of the Co-authors:

N. BARUWATI, Department of Botany Gargaon College, Simaluguri, SIVASAGAR (ASSAM) INDIA 